\title{
Structural and floristic classifications of Cape Mountain Fynbos on Rooiberg, southern Cape
}

\author{
H. C. TAYLOR* and F. VAN DER MEULEN**
}

\section{ABSTRACT}

Structure and floristic composition of the plant cover were used to establish separate classifications of plant communities in Mountain Fynbos on Rooiberg, South Africa. The structural units and floristic associations closely correlate with each other and their distribution reflects the major environmental influences, aspect and altitude. It is concluded that, despite the preliminary character of the survey, resource inventories of this type are suitable as a foundation for park management.

\section{RÉSUME}

\section{LES CLASSIFICATIONS STRUCTURALES ET FLORISTIQUES DES BUISSONS DE LA MONTAGNE DU CAP SUR ROOIBERG, CAP AUSTRAL}

La composition structurale et floristique de la couverture de plantes ont été utilisés pour établir des classifications separées de communautés de plantes dans le Fynbos de Montagne sur Rooiberg, en Afrique du Sud. Les unités structurales et les associations floristiques correspondent les unes avec les autres et leur distribution réflète les influences du milieu, de l'aspect et de l'altitude. Il en est conclu que, malgré le caractère préliminaire de l'étude, la ressource d'inventaires de ce type convient comme la fondation pour la conduite de parcs.

\section{INTRODUCTION}

At the request of the Department of Forestry, the first author carried out a survey of the False Macchia (Acocks, 1975) or Mountain Fynbos vegetation of the Rooiberg Mountain Catchment Area to provide basic data for a management plan (Taylor, in press). For this purpose, a simple classification, description and map were needed, dividing the vegetation into units that are visually homogeneous in physiognomy. Because these units had to be recognized by nonbotanical personnel, it was decided to adopt a structural classification, rather than a floristic one. The structural survey was done by marking units of more or less uniform vegetation structure and terrain morphology on air photos (scale 1:20 000). These units were then studied in the field. In about a month's field work, sufficient information was gathered to delineate eight major structural units and 20 variations, all of which could be related to habitat. These have been mapped $(1: 50000)$ and described in detail by Taylor (in press).

Management of Mountain Fynbos reserves such as Rooiberg aims at maximum production of clear water from catchments and the maintenance of vegetation diversity both in plant species and plant life forms. Hence, a vegetation study for management purposes should include both a floristic and a structural description. Time did not permit an extensive phytosociological survey on Rooiberg. However, to determine whether the major structural units could also be distinguished by their species composition, a brief Braun-Blanquet survey was carried out. Twenty-eight rélevés were laid out subjectively within stands of vegetation that were regarded as representative of the main structural units. In the phytosociological table only vascular plants were taken into account. This paper summarizes and compares the results of the structural and floristic surveys. For in-

* Botanical Research Unit, P.O. Box 471, Stellenbosch 7600.

**Formerly, Botanical Research Institute, Pretoria. Present address: Dune Waterworks of the Hague, Pompstationsweg 315, 2597 J. V. Scheveningen, Netherlands. formation on the flora and phytogeography of Rooiberg we refer to Taylor (1979).

\section{LOCATION AND HABITAT}

About $20 \mathrm{~km}$ south-east of Ladismith, Cape Province (Fig. 1), lies a west-east trending mountain range, divided into more or less equal sections by the Gouritz River. The Rooiberg Mountain Catchment Area, 25345 ha in extent, comprises a large part of the higher western section of this range at approximately $33^{\circ} 40^{\prime} \mathrm{S}$ latitude and $21^{\circ} 30^{\prime} \mathrm{E}$ longitude. It consists of State and private land, managed by the Department of Water Affairs, Forestry and Environmental Conservation for the conservation of water, flora and wild life.

The range is one of a series of isolated mountains located between Montagu and Uniondale, the fynbos of each mountain being separated from that of its neighbours by karroid lowland vegetation of the Little Karroo.

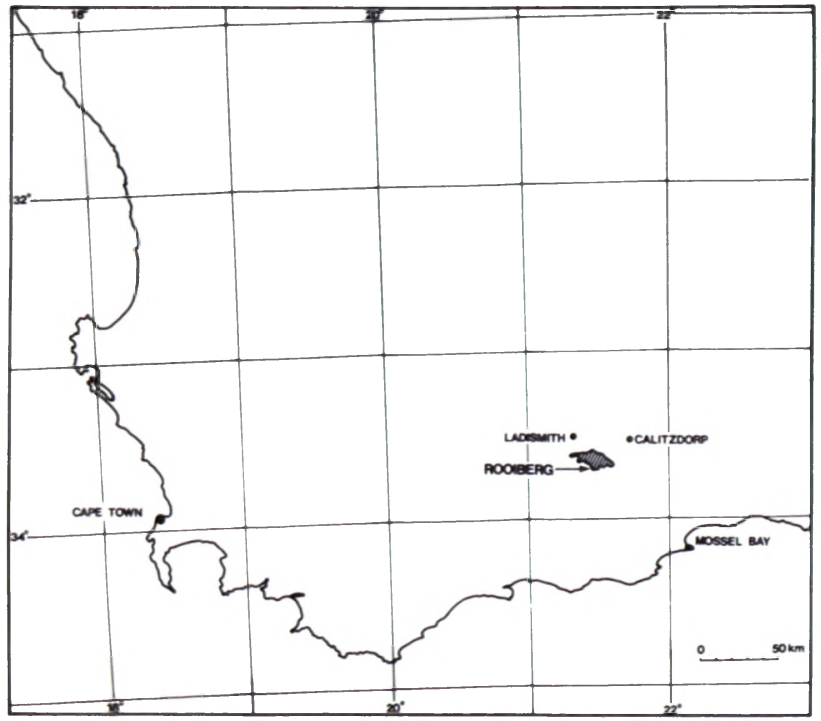

FIG. 1.-Map showing location of Rooiberg in southern Cape. 
Geomorphologically, the Rooiberg Range is a broad anticlinal fold of Table Mountain Sandstone strata, breached near the top of the arch. The breach has eroded to form a series of deeply incised kloofs that run parallel to the main crest before breaking south in deep gorges that have cut through subsidiary crests. The Table Mountain Sandstones are interrupted by a shale band that can be traced as a sinuous line across the north side of the range. Sandy lithosols cover the greater part of the reserve. Rock outcrops and cliffs are common in the interior kloofs but the main north-and south-facing sides of the range are not excessively steep.

The climate is hot and dry. Situated on the transition between the winter- and summer-rainfall areas, Rooiberg receives only the outer fringe of the winter cyclonic rains and few summer thunderstorms. The mean total precipitation for 1977/1978 (the first year after rain gauges were erected) was about $365 \mathrm{~mm}$, the northern side of the mountain receiving about half as much rain as the southern slopes (P. B. Odendaal, pers. comm.). Probably the most effective precipitation is from condensation of the clouds that form around the high peaks. Considerable temperature and moisture differences may be expected between crests (about $1400 \mathrm{~m}$ altitude) and footslopes of the mountain (about $800 \mathrm{~m}$ ).

\section{VEGETATION \\ 1. Structural units}

The vegetation units identified in the structural survey depict only gross structural characteristics. They are based on simple criteria such as estimated height and canopy cover of the vegetation and estimated proportion of (i) restioid, (ii) narrow-leaved and (iii) proteoid components. These components characterize fynbos vegetation. For convenience, their definitions are repeated here. (i) Restioid refers to hemicryptophytic plants of the family Restionaceae with sclerophyllous tubular stems and leaves that have been reduced to membranous, nonphotosynthetic scales or small sheaths arising singly from each node. They are often tufted but sometimes rhizomatous. The category includes plants in other families that have a physiognomy similar to the Restionaceae, for example, most Tetraria and Ficinia species, some Juncus species and Typha. (ii) Narrowleaved means the very narrow leptophylls, usually sclerophyllous though some may be fleshy or even succulent. It includes flat, involute and cylindrical leaves as well as revolute leaves like those of the Ericaceae. The term had to be substituted for 'ericoid' which is now restricted to revolute sclerophyllous leptophylls. (iii) Proteoid is the term for plants with leaves and growth form resembling proteas. They have isobilateral leaves with the shape and texture of a typical protea e.g. Protea lorifolia, $P$. repens or broader leaves like $P$. nitida and $P$. cynaroides. Broad-leaved is used here to denote the roughly ovate, sclerophyllous leathery leaves of woody shrubs derived from the northern floras as against those of typical fynbos plants (e.g. Cassine, Maytenus, Euclea).

The vegetation units appeared to be suitable mapping units. Where local aspect might significantly affect the vegetation and therefore the management, variations were distinguished within the major structural units. In our description the following letters have been used: $\mathrm{N}=$ communities on slopes of northerly aspects, $\mathrm{S}=$ communities on southerly aspects, $\mathrm{C}=$ communities of crests and $\mathrm{K}=$ communities of very steep kloofs. Relative positions of the communities on Rooiberg are shown in Fig. 2.

\section{Communities with northerly aspects}

Community N1. This community, comprising Variations Nla, NIb, C1, C2, is found on the moderately steep upper and middle slopes $(1370-1060 \mathrm{~m})$ to the north of the divide. The vegetation is a closed restioid and narrow-leaved shrubland in which the former element is often predominant or at least conspicuous. Variation Nla of the highlands east of Rooiberg Peak is mainly restioid and about $0,5-1 \mathrm{~m}$ high (Fig. 3). Most of the precipitation in this area comes from the condensation of clouds formed by the summer south-east winds. The land is privately owned and was probably burned fairly frequently in the past.

Variation C1 (Fig. 4) occurs on summits and is stunted because of its exposed site. It is sometimes dominated by grasses. Many of the localities, too small to be mapped separately, have been included in Variation C2 which occurs along the crest and major spurs at high altitude. This variation has a higher species diversity and greater variety in dominance and height of species due to many local differences in aspect and degree of slope (Fig. 5). Since the major fire belts are sited on ridges, the Variations $\mathrm{Cl}$ and $\mathrm{C} 2$, like $\mathrm{N} 1 \mathrm{a}$, have been subject to more frequent and regular burning than other parts of the reserve.

Variation $\mathrm{N} 1 \mathrm{~b}$, less frequently burnt, represents vegetation of northerly aspects west of Rooiberg Peak and below Variations $\mathrm{C} 1$ and $\mathrm{C} 2$. Low narrow-

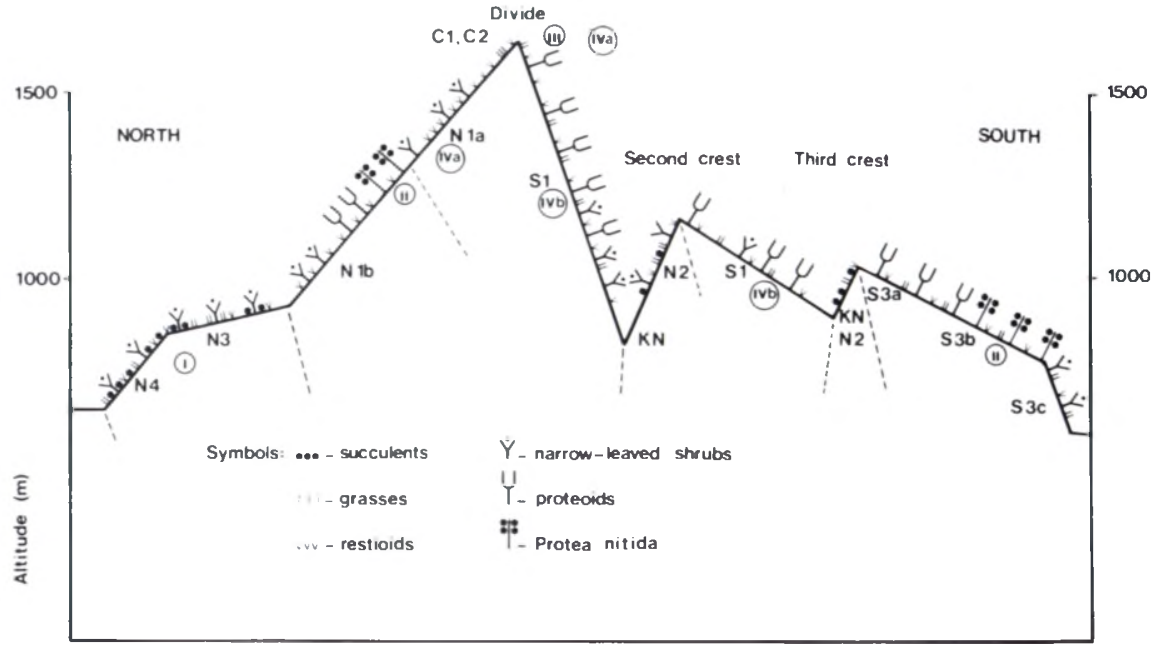

FIG. 2.-Relative positions of communities on Rooiberg. 
FIG. 3.-Variation N1a above the headwaters of Groenkloof, east of Rooiberg Peak.
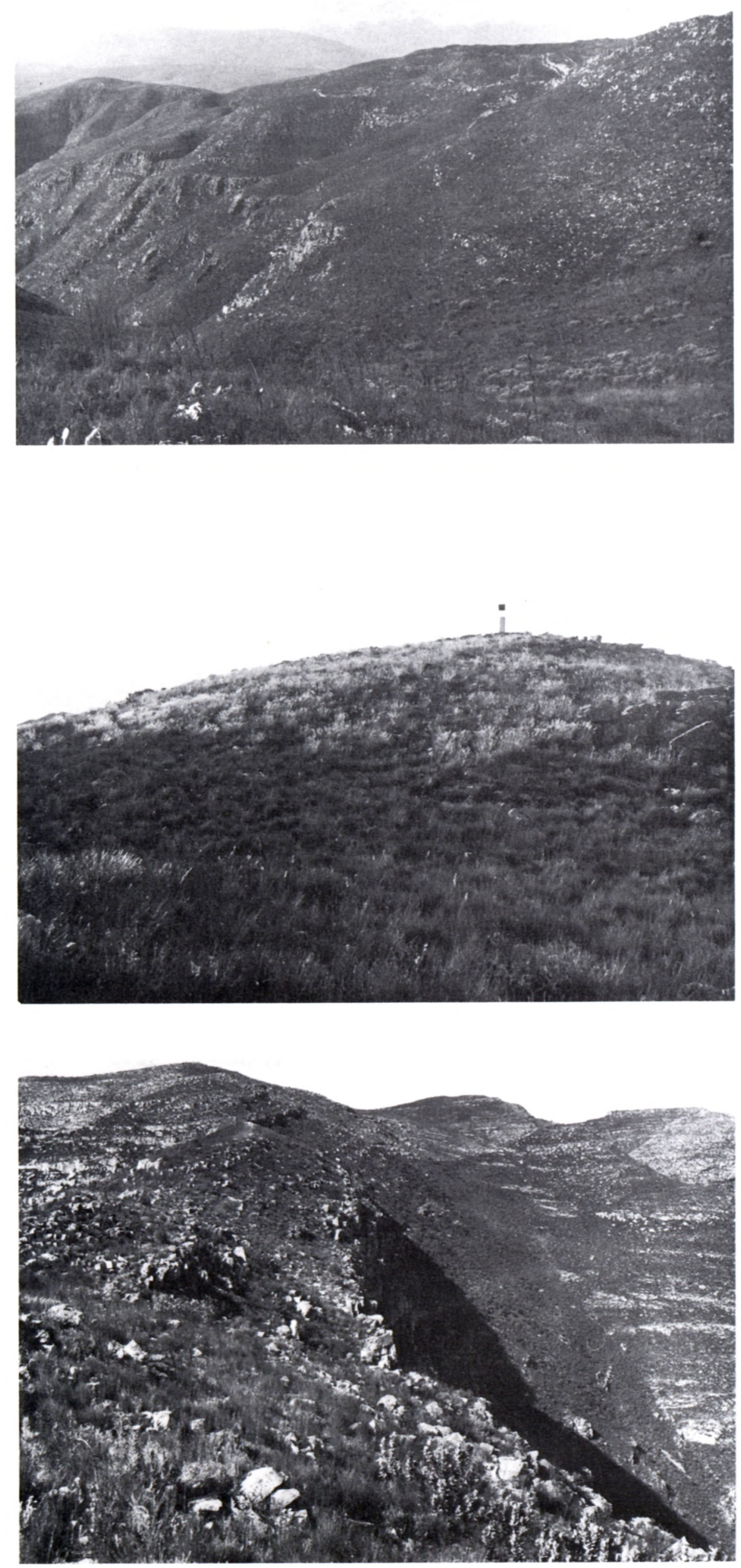
leaved shrubs prevail, but at middle altitudes the proteoid element (Protea repens, $P$. eximia, $P$. lorifolia) increases in height (up to $2 \mathrm{~m}$ ) and cover (up to $75 \%$ ) (Fig. 6). Leucadendron salignum extends in a broad belt across the middle slopes, giving them a yellow-green speckled appearance. At the middle altitudinal limit of this variation is a similar belt of the grey-leaved small tree, Protea nitida (Waboom) which, though less widespread than Leucadendron salignum, often overlaps its range. This 'Waboomveld' is recognizeable on air photos but is too restricted in area to map separately.

Community $N 2$. Including Variations $N E$ and $N W$, this community occurs between about 1300 and $650 \mathrm{~m}$ on steep northerly slopes beneath the second crest (Fig. 7). These lower slopes receive less cloud moisture and are therefore warmer and drier than those of Variation Nla, north of the divide. Narrow-leaved shrubs exceed restioids in cover while proteoids are rare and of a more xeromorphic type, like Protea lorifolia. The community contains a fair number of succulents and grasses although their cover is not high. Sites with north-east and northwest aspects are separated as Variations NE and NW respectively. The narrow-leaved shrub Passerina vulgaris tends to dominate on both aspects and Protea punctata occurs locally on upper slopes in variation NE.

Community N3. This community is found between 1060 and $900 \mathrm{~m}$ on the plateau or shelf on the northern side of the mountain below Variation N1b. Slopes are gentle to almost level and very stony. The vegetation, about one metre in height, is characterized by the predominance of narrow-leaved shrubs in the upper canopy (Fig. 8). In lower layers, restioids, grasses and succulents (mainly Mesembryanthemaceae) can be quite numerous.

At the western limit of the range or at the outer edge of the plateau where less rain falls, elements of Renosterveld, especially the Renosterbos (Elytropappus rhinocerotis), become conspicuous.

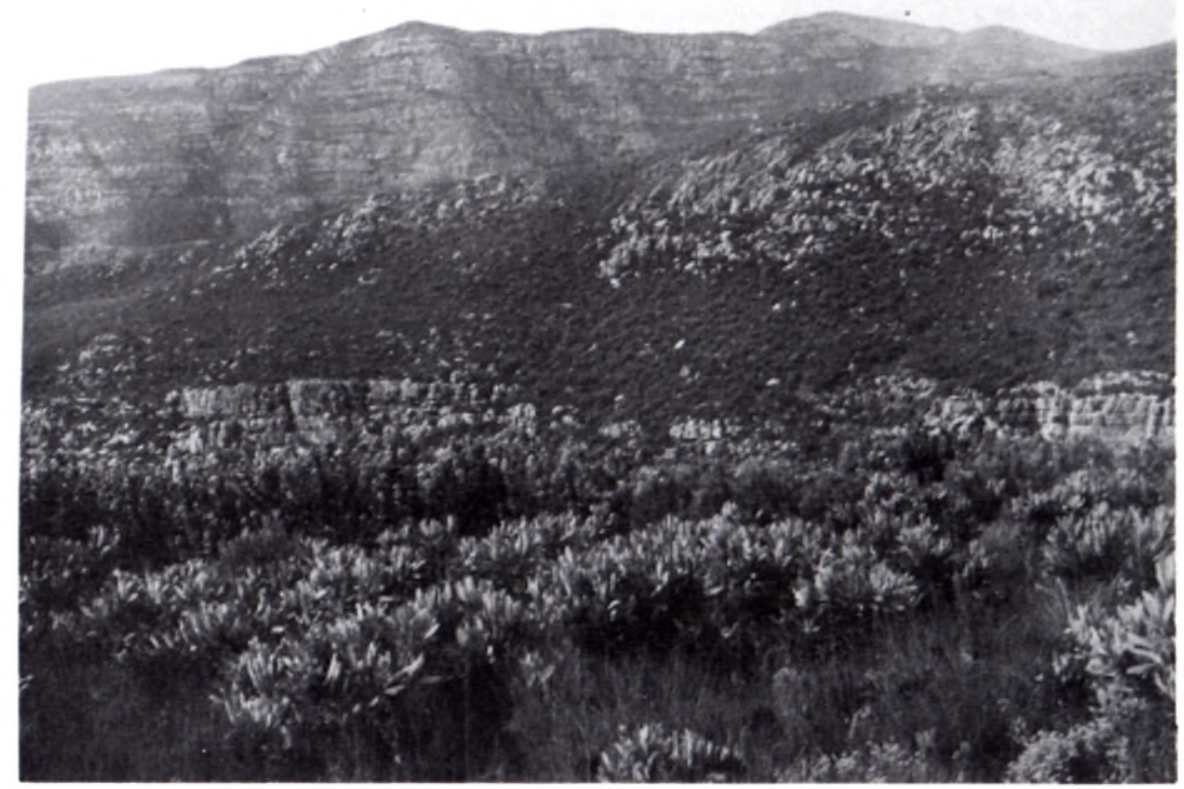

FIG. 6.-Variation N1b where the proteoid cover reaches up to $75 \%$ : Protea lorifolia in the foreground, $P$. eximia behind, c. 1-2 m.

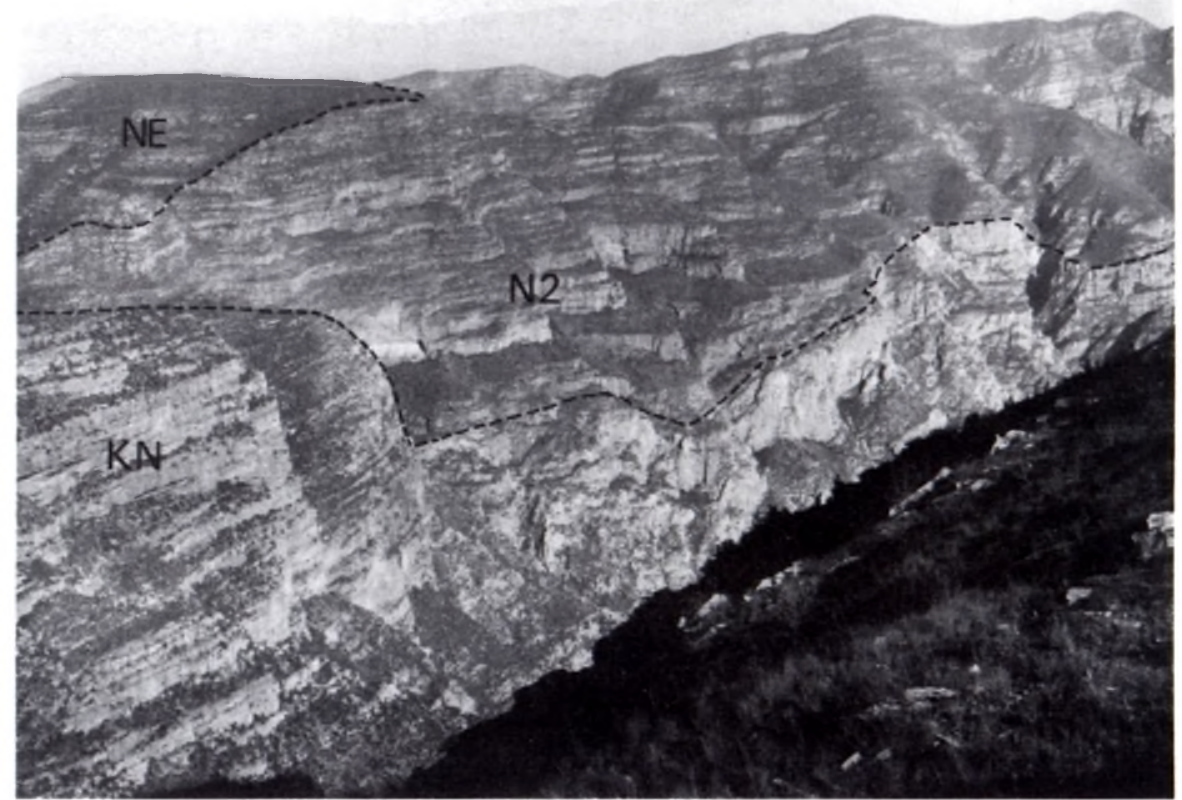

FIG. 7.-The second crest showing Community $\mathrm{N} 2$ between the skyline and the steep cliffs. Variation NE the darker patch at top left, and Community KN on the precipitous lower slopes. 
FIG. 8.-At Nicolaaskloof, typical Community $\mathrm{N} 3$ is confined to the sloping shelf in the foreground. On the rocky slopes beyond, N3 intergrades with proteoid Nlb above the figure's head.

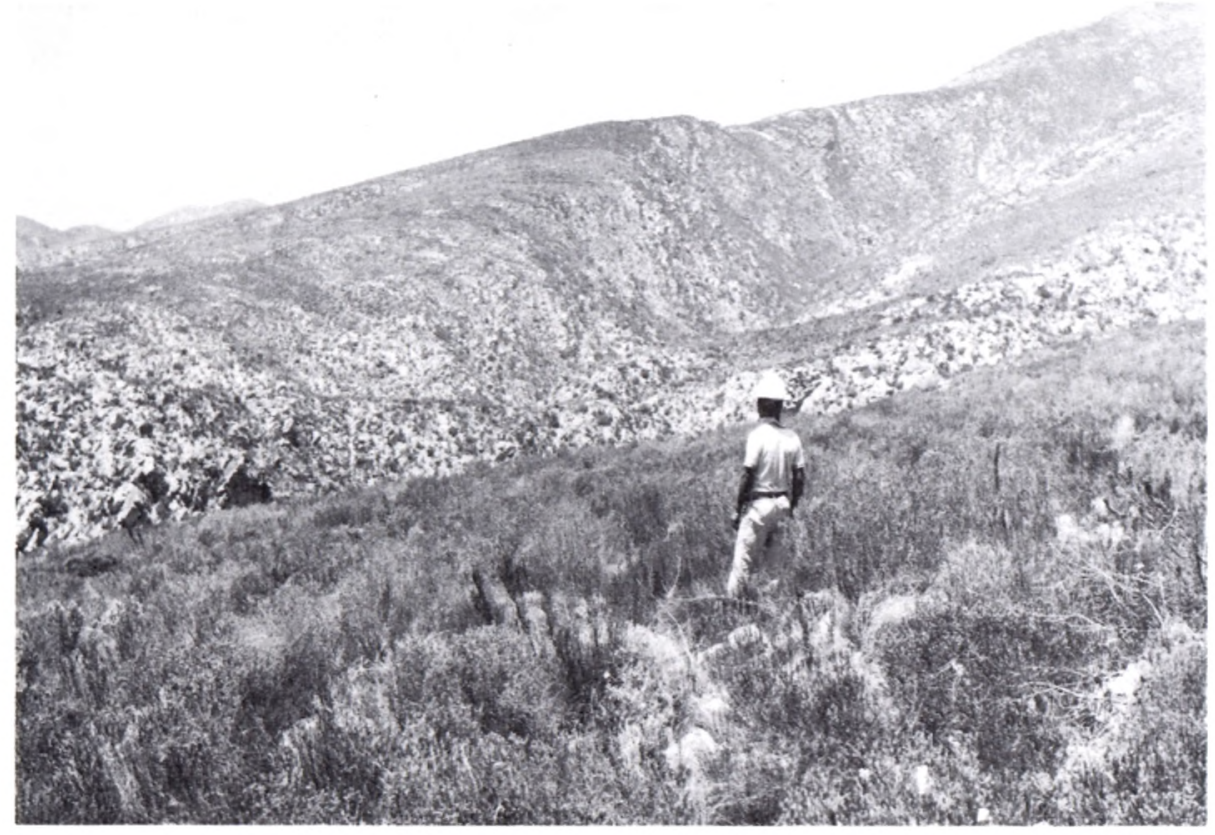

FIG. 9.-Community $\mathrm{N} 4$ on the steep north-facing basal slope.

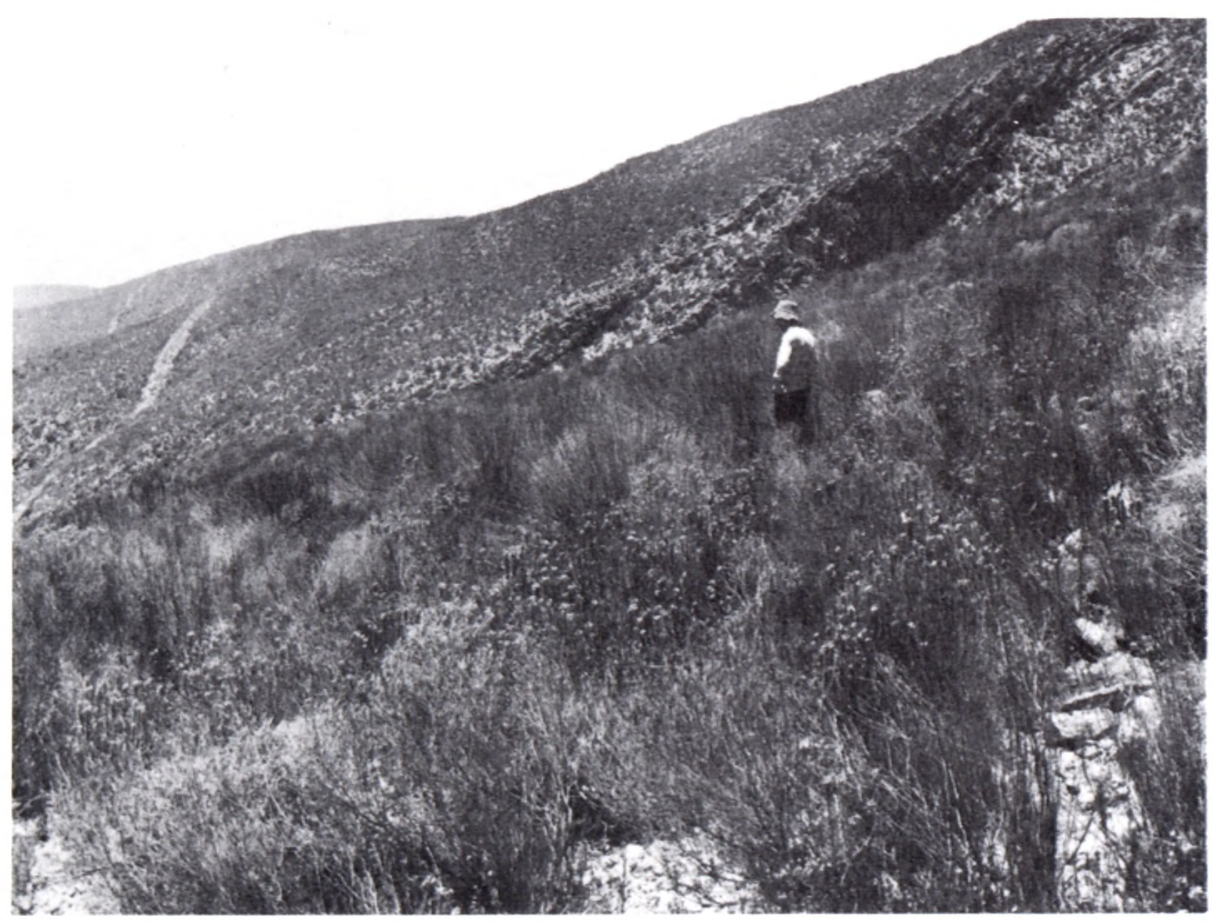

Community N4. This community occurs on steep north-facing slopes between 900 and $700 \mathrm{~m}$, below Community N3 down to the base of the mountain. The soils are very stony, shallow and dry. Like the previous one, Community $\mathrm{N} 4$ is dominated by narrow-leaved shrubs (Fig. 9) but the vegetation is more open and poorer in species content, containing some karroid elements and more succulents than usual in fynbos because this community borders on the karroid vegetation of the lowlands.

Community $K N$ (including Community $K$ ). The main drainage of upper Rooiberg comprises four complex kloof systems that occupy the rift south of the divide. In their upper reaches the kloofs run parallel to the divide and then drain south. The north side of the range is drained by five large kloofs running east or north-east and a series of shorter, shallower kloofs running north. Community $\mathrm{KN}$ is found at lower levels of all the southward draining kloofs.
The habitat is a very steep to precipitous rock slope with some soil accumulated in pockets and bands between the vertical cliffs (Figs $7 \& 10$ ). The kloofs draining north or north-east have no distinct north or south aspects, but the vegetation of their steep sides, Community $\mathrm{K}$, appears structurally similar to that of Community $\mathrm{KN}$. In both communities the canopy cover is low (about 25-70\%) and consists of scattered shrubs with a rounded growth form $1-2 \mathrm{~m}$ in diameter, interspersed with coarse restioids and grasses, some broad-leaved bushes of tropical affinity (e.g. Diospyros dichrophylla and Cussonia spicata) and succulents in the ground layer. Proteoids are usually absent. The vegetation, like the habitat, is very similar to $\mathrm{N} 4$.

\section{Communities with southerly aspects}

Community S1. This community, which includes Variations $S W$ and $S E$, is found on moderately steep 
to very steep southerly slopes from 1490 m down to about $630 \mathrm{~m}$. The well drained, shallow soil consists of fine grey humic sand with some leaf litter. At high elevations, these slopes receive moisture condensed from the clouds that form in the south-east wind, therefore reducing the effect of the hot, dry summers. The vegetation is dense shrubland with a closed, uniform canopy of proteoids up to $2 \mathrm{~m}$ high. There is at least one lower layer of restioids and narrow-leaved shrubs similar in structure to the canopy of Community Nla.

Within Community S1 there are several structural variations, possibly resulting from differing proteoid dominance: at the highest, steepest sites, Protea punctata occurs in almost pure stands with some Leucadendron comosum (Fig. 11); at middle altitudes Leucadendron eucalyptifolium becomes either dominant or co-dominant with Protea punctata. At still lower elevations, the number of proteoid species increases with the addition of Protea eximia and $P$. neriifolia but their total cover decreases until at the lowest parts the proteoid layer contributes about $50 \%$ canopy cover and is only about $1 \mathrm{~m}$ high, while the restioid and narrow-leaved layer becomes closed. Since these structural variations either form mosaics or intergrade with each other, they cannot be mapped separately at the 1:50 000 scale. Variations $S W$ and $S E$, with western and eastern aspects respectively, are mappable units of the open proteoid community of lower altitudes down to about $400 \mathrm{~m}$, which include Protea repens, $P$. lorifolia and Leucadendron salignum. Grasses are also more frequent in these variations than in the other variations of Community S1.

Community S2. This community was found only in a small area on the steep upper south-easterly slopes of the peak marked by Trigonometrical Survey beacon No. 149. Stands on similar sites on the highest peaks, which possibly belong to the same community, have been affected by a fire belt. Shallow, black, humic soil, more moist than other Rooiberg soils, occurs between the bands of outcrop-
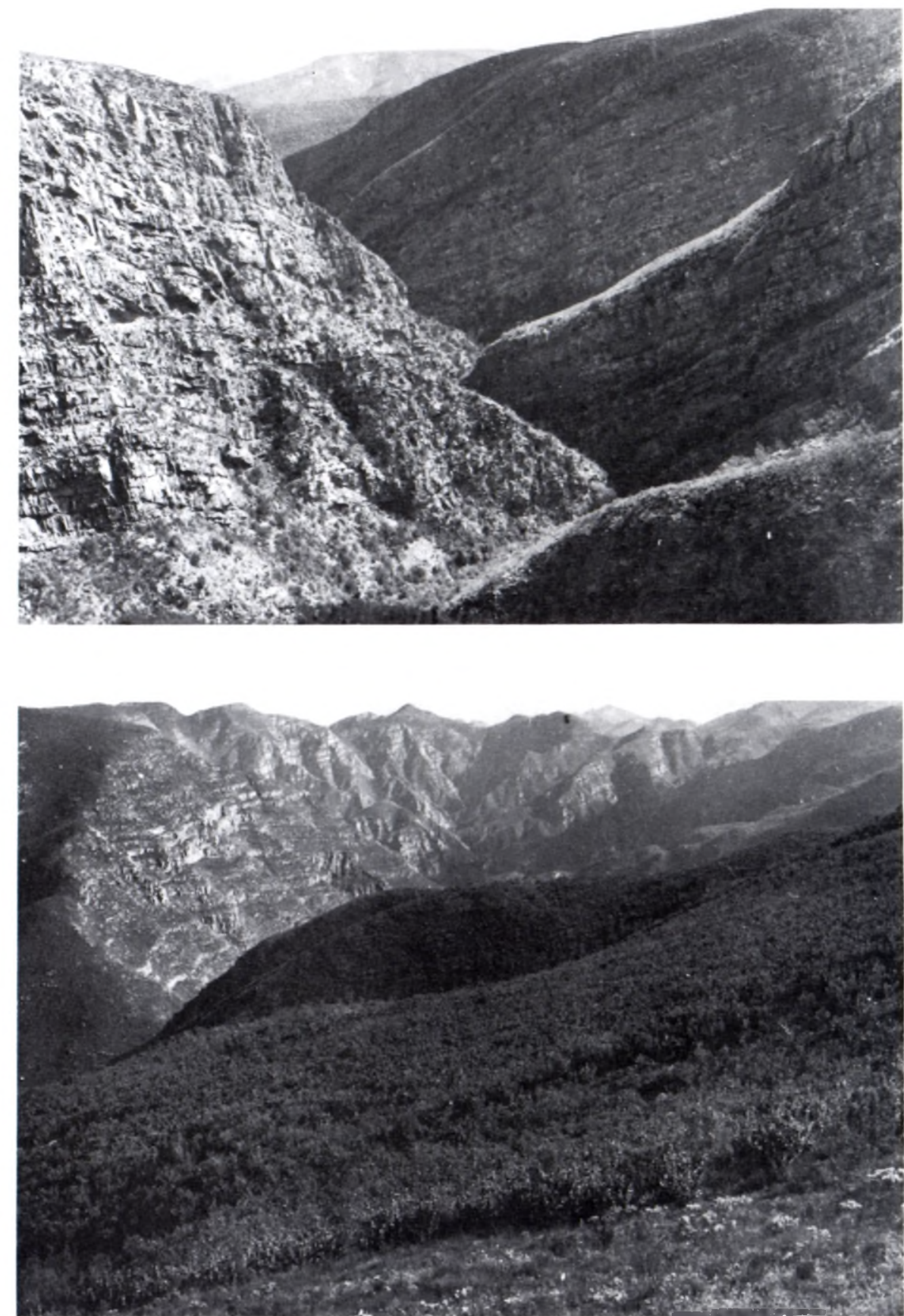

FiG. 10.-North-facing krans on the left with vestiges of Community $\mathrm{KN}$ at its base. Gorge of the south-flowing Bosrivier.
FIG. 11.-Tall dense proteoid shrubland of Community S1 dominated by Protea punctata with a fringe of $P$. eximia in front, bordering on a fire-belt in the foreground where restioids and narrow-leaved shrubs of the lower layer are prominent. 
TABLE 1.-Floristic classification of communities on Rooiberg (compare with Fig. 2) $x=$ occurring in close vicinity of releve $\mathrm{P}=$ proteoid; $\mathrm{R}=$ restioid $($ Restionaceae); $(\mathrm{R})=$ restioid (other families); $\mathrm{S}=$ succulent; $\mathrm{O}=$ other forms.

Community number

II

III

IVa

IVb

Altitude ( $\mathrm{m})$

Structural units

Total number of species

Relevé number

Differential species for community of northern lower slopes

Zygophyllum sp. (rel. 487)

Euryops erectus

N Aspalathus granulata

Relhania squarrosa

S Mesem. sp. (No. 123)

Differential species for community of middle slopes

P Protea nitida

O Mohria caffrorum

Eroeda imbricata

(N) Pelargonium myrrhifolium

Elytropappus glandulosus

Sutera stenophyll

Leucadendron salignum

Carpobrotus sp. (rel. 448)

Chamaraea capensis

B Euclea polyand

Differential species for communities of lower and middle slopes

Eriocephalus umbellulatus

Aspalathus sceptrum-aureum

Hermannia odorata

Phylica rigidifolia

Restio gaudichaudianus

Merxmuellera arundinacea

Elytropappus rhinocerotis

Aspalathus hir

Differential species for community of

Summits and crest

Rut aceae (Taylor 9210)

Helichrysum ericoides

Gazania linearis

Crassula sp., cf. cephalophora

Differential species for communities of lower and middie slopes and crest

G Pentaschist is eriostoma

R) Ficinia nigrescens

Differential species for community of southern upper slopes

Protea punctata

Leucadendron comosum

Leucadendron

Elegia juncea

Erica sp., cf. quadrangularis

Differential species for community of

upper slopes
Tetraria ustulata

R) Tetraria involucrat

O Nivenia capitata

Protea eximia

Erica cerinthoides

Erica hispidula

Spatalla confusa

(R) Tetraria sp., cf. cuspidata

Differential species for communities of

crest and upper slope

Aspalathus rubens

H Hypolaena purpurea

(N) Struthiola martiana

(N) Agathosma ovalifolia

P Protea repens

$R$ Elegia galpinii

Cliffortia ruscifolia

Cliffortia ruscifolia
Cliffortia tuberculata

Ursinia sericea

Lobelia coronopifolia

Thoracosperma galpinii

Ficinia ixioides

Restio hystrix

Companions

Restio fruticosus

Passerina vulgaris

Helichrysum paniculatum

Thamnochortus argenteus

Hypodiscus stria

Anthospermum ciliare

Cliffortia crenata

Ehrharta ramosa

Ficinia filiformis

Phylica purpurea
Crassula lycopodioides

Crassula lycopod
Restio triticeus

And the following number of species

occurring in less than 8 releves

\begin{tabular}{|c|c|c|c|c|}
\hline $\begin{array}{lllllllll}8 & 8 & 8 & 9 & 8 & 7 & 6 & 9 & 8 \\
5 & 2 & 0 & 1 & 5 & 7 & 4 & 6 & 3 \\
3 & 3 & 0 & 4 & 3 & 7 & 0 & 0 & 8\end{array}$ & $\begin{array}{llllll} & & & 1 & & \\
5 & 6 & 8 & 0 & 6 & 5 \\
6 & 2 & 8 & 8 & 4 & 0 \\
4 & 5 & 4 & 2 & 0 & 3\end{array}$ & $\begin{array}{lllll}1 & 1 & 1 & 1 & 1 \\
4 & 4 & 3 & 2 & 2 \\
6 & 9 & 1 & 5 & 9 \\
9 & 0 & 2 & 0 & 5\end{array}$ & $\begin{array}{llll}1 & 1 & 1 & 1 \\
4 & 3 & 4 & 3 \\
1 & 7 & 1 & 1 \\
0 & 0 & 7 & 1\end{array}$ & $\begin{array}{llll}1 & 1 & 1 & 1 \\
3 & 3 & 4 & 3 \\
8 & 4 & 0 & 2 \\
5 & 1 & 2 & 6\end{array}$ \\
\hline $\begin{array}{lllllllll}N & N & N & N & N & N & N & N & N \\
4 & 4 & 4 & 3 & 3 & 3 & 3 & 3 & 3\end{array}$ & $\begin{array}{llllll}S & S & S & N & S & S \\
3 & 3 & 3 & 1 & 3 & 3 \\
& & & b & & \end{array}$ & 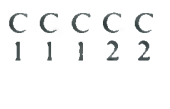 & $\begin{array}{llll}N & N & C & C \\
1 & 1 & 2 & 1 \\
a & a & & \end{array}$ & $\begin{array}{llll}\mathbf{S} & \mathbf{S} & \mathbf{S} & \mathbf{S} \\
1 & 1 & 1 & 1\end{array}$ \\
\hline $\begin{array}{lllllllll}1 & 1 & 3 & 2 & 2 & 2 & 2 & 5 & 4 \\
7 & 4 & 5 & 9 & 1 & 9 & 3 & 3 & 0\end{array}$ & $\begin{array}{llllll}7 & 5 & 5 & 4 & 4 & 3 \\
4 & 0 & 1 & 5 & 9 & 9\end{array}$ & $\begin{array}{lllll}3 & 3 & 3 & 3 & 3 \\
2 & 9 & 0 & 4 & 8\end{array}$ & $\begin{array}{llll}3 & 4 & 4 & 3 \\
2 & 5 & 3 & 8\end{array}$ & $\begin{array}{llll}4 & 4 & 2 & 3 \\
8 & 5 & 7 & 6\end{array}$ \\
\hline $\begin{array}{lllllllll}4 & 4 & 4 & 4 & 4 & 4 & 4 & 4 & 4 \\
7 & 8 & 3 & 7 & 8 & 8 & 8 & 2 & 2 \\
5 & 5 & 3 & 3 & 6 & 8 & 7 & 9 & 8\end{array}$ & $\begin{array}{llllll}4 & 4 & 4 & 4 & 4 & 4 \\
4 & 4 & 3 & 4 & 7 & 4 \\
7 & 4 & 7 & 2 & 1 & 8\end{array}$ & $\begin{array}{lllll}4 & 4 & 2 & 4 & 4 \\
7 & 3 & 2 & 3 & 3 \\
4 & 0 & 2 & 6 & 9\end{array}$ & $\begin{array}{llll}4 & 4 & 4 & 4 \\
3 & 3 & 0 & 7 \\
4 & 2 & 5 & 2\end{array}$ & $\begin{array}{llll}4 & 4 & 4 & 4 \\
3 & 4 & 3 & 3 \\
5 & 1 & 1 & 8\end{array}$ \\
\hline
\end{tabular}

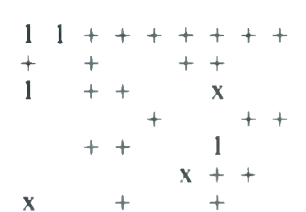

21211
$+1+2$

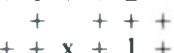

$++++++$

$++2+$

$+2+$

$x^{+} x^{+}$

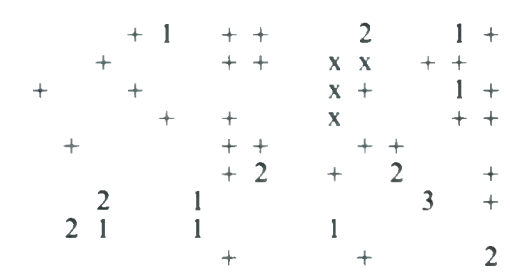

$+1+$

$+2$

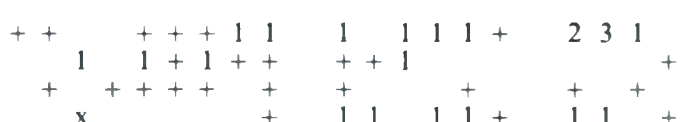

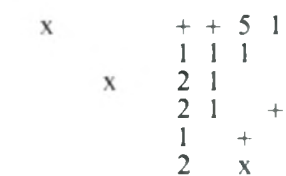

$12++31+$

$2 \times++++x^{+}+$

$\begin{array}{lll}\times 1 & 1+ \\ + & +\end{array}$

12

$+++$

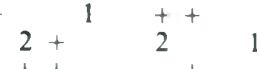

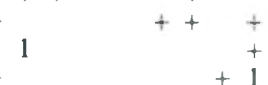

$+$

$1+3201+\quad+1 x++12+23+++3++++$

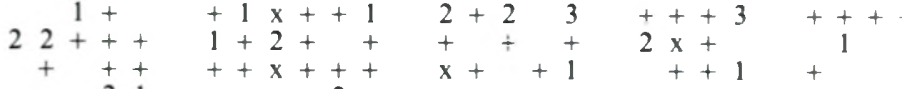

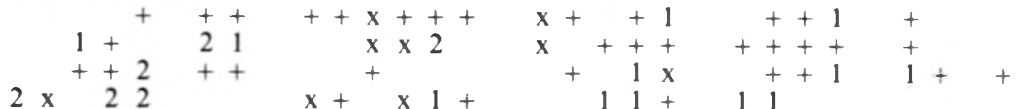

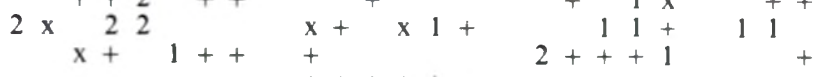

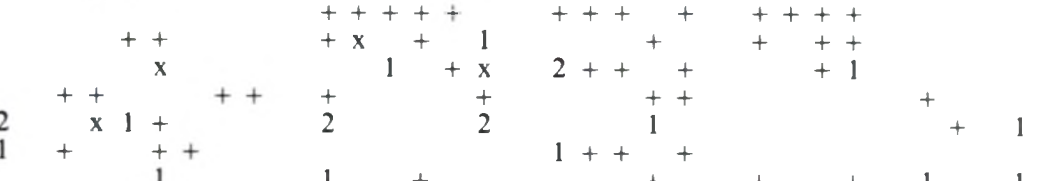

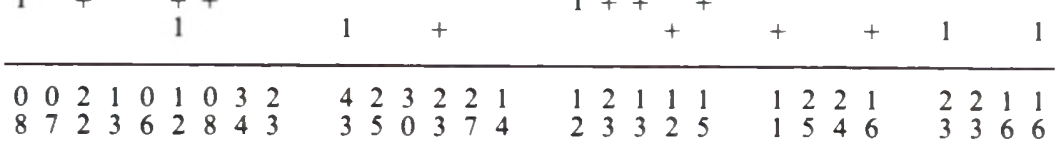



Fig. 12.- The dense, narrowleaved shrubland Community S2 on a cool, moist slope.
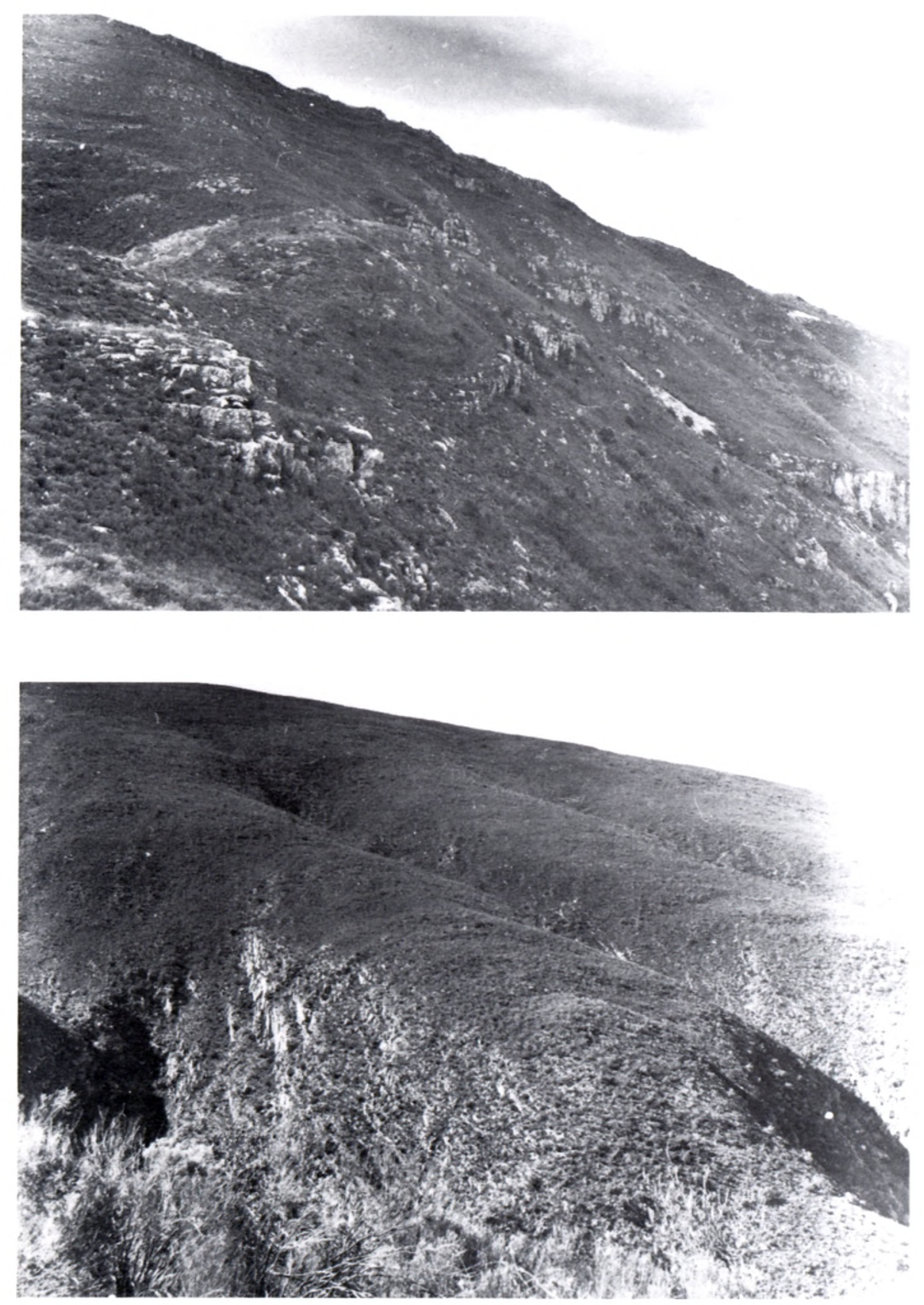

species in the reserve; the understorey is chiefly restioid. A belt of Waboomveld, with Protea nitida conspicuous, extends along the middle slopes from about $760 \mathrm{~m}$ to $640 \mathrm{~m}$ (Community $S 3 \mathrm{~b}$ ); narrowleaved shrubs predominate and grasses are fairly frequent (Fig. 13). Along the lowest slopes, especially to the west, is a zone of karroid narrow-leaved shrubs (e.g. Pteronia, Relhania) about 1,5 m high constituting up to $75 \%$ canopy cover, in which the coarse tufted grass Merxmuellera arundinacea is often conspicuous (Community S3c.)

\section{Floristic units}

We have sampled the vegetation by means of Braun-Blanquet relevés (Table 1) varying in size from the usual $50 \mathrm{~m}^{2}$ to about $100 \mathrm{~m}^{2}, 200 \mathrm{~m}^{2}$ or $300 \mathrm{~m}^{2}$ depending on differing vegetation structure. Some units, like S1, are undersampled, the rare ones like S2, KN \& N2 are not sampled at all, while others have been sampled more intensively because of their special interest, e.g. the Protea nitida-dominated Waboomveld which occurs in different floristic subdivisions throughout the range of Mountain Fynbos.
FIG. 13.-Scattered Waboom (Protea nitida) barely discernible in the narrow-leaved matrix of Community S3 on the middle slopes above Buffelsfontein. 
TABLE 2.-Comparison of structural and floristic units

\section{Structural unit (and variations)}

$\begin{array}{ll}\begin{array}{l}\text { Floristic } \\ \text { unit }\end{array} & \begin{array}{l}\text { Main habitat } \\ \text { characteristics }\end{array} \\ \text { III, IVa } & \begin{array}{l}\text { Highlands and crests } \\ \text { (Nla, C1, C2); mode- } \\ \text { rately steep upper and } \\ \text { middle northern slopes } \\ \text { (NIb) }\end{array} \\ \text { (II) } & \end{array}$

Not sampled

Steep northern slopes beneath the second crest

\section{N3 Fairly dense narrow-leaved and restioid shrubland up to $1 \mathrm{~m}$ with} grasses and succulents

N4 Fairly open narrow-leaved shrubland up to $1 \mathrm{~m}$ with succulents and karroid elements

KN (incl. K) Open narrow-leaved and broad-leaved shrubland up to $1,75 \mathrm{~m}$ with coarse restioids, grasses and succulents

S1 (incl. SW, SE) Dense proteoid shrubland up to $2 \mathrm{~m}$ with lower restioids and narrow-leaved shrubs

S2 Dense narrow-leaved shrubland up to $1,5 \mathrm{~m}$

S3 (incl. S3a, b, c) Fairly dense mixed proteoid shrubland up to $1,5 \mathrm{~m}$ (S3a); narrow-leaved shrubland ( $1 \mathrm{~m})$ with Protea nitida conspicuous and emergent to $2,5 \mathrm{~m}$ (S3b); fairly open narrow-leaved karroid shrubland to $2 \mathrm{~m} \mathrm{(3c)}$
Gentle to almost level lower northern slopes

\section{Not sampled}

IVb

Not sampled

II $(=\mathrm{S} 3 \mathrm{~b})$

S3a, c not sampled
Very steep rock slopes of kloofs

Steep lower northern slopes beneath community N3

Moderate to very steep upper southern slopes

Steep upper southern slopes (limited area)

Gentle to moderate lower southern slopes: upper (S3a), middle (S3b) and lower (S3c) zones; one relevé on north side of mountain
Predominant species
Restio fruticosus, R. cuspidatus, Thamnochortus argenteus, Hypodiscus purpureus, Tetraria ustulata. Centella virgata, Lightfootia rigida, Aspalathus rubens. Pentaschistis eriostoma, $P$. colorata, Ehrharta ramosa.

Passerina vulgaris, Elytropappus glandulosus, Muraltia spp., Restio spp.

Felicia filifolia, Anthospermum aethiopicum, Passerina vulgaris, Elytropappus rhinocerotis (loc.), Euryops erectus, Relhania squarrosa, Phylica rigidifolia. Restio fruticosus, Hypodiscus striatus, Thamnochortus argenteus. Pentaschistis eriostoma, Merxmuellera arundinacea, Mesems, Crassula spp.

Metalasia pallida, Phylica purpurea Cullumia bisulca. Diospyros dichrophylla Restio fruticosus. Merxmuellera arundinaceae. Crassula spp.

Protea punctata, Leucadendron comosum, L. eucalyptifolium, Erica hispidula, E. calycina. Elegia juncea, Tetraria ustulata

Berzelia intermedia, Psoralea pinnata. Cannamois virgata

Protea repens, $P$. neriifolia $(\mathrm{S} 3 \mathrm{a})$; Protea nitida, Leucadendron salignum (S3b). Anthospermum ciliare, Elytropappus glandulosus, Lightfootia rigida, Aspalathus sceptrum-aureum, Sutera stenophylla, Eroeda imbricata. Restio cuspidatus, Ficinia deusta. Pentaschist is eriostoma, Cymbopogon marginatus; Themeda triandra (S3b)

\section{COMPARISON OF STRUCTURAL AND FLORISTIC UNITS}

A comparison of the structural and floristic units is summarized in Fig. 2 \& Table 2.

Community I. Of the lower northern slopes this community comprises all relevés in structural units $\mathrm{N} 3$ and N4. Predominant growth forms include restioids (Restio fruticosus, Thamnochortus argenteus, Hypodiscus striatus) and narrow-leaved shrubs (Felicia filifolia, Passerina vulgaris). The first three releves of this community are located in structural unit $\mathrm{N} 4$ which, it was noted, is poorer in species than N3. In fact, Relevés 475 and 485 have the lowest species content of any in the survey.

Community II. This 'Waboomveld' community represents stands of middle and lower slopes mainly with southerly aspects (structural unit S3b) characterized not only by Protea nitida but also by Mohria caffrorum and Pelargonium myrrhifolium, species that are frequent in Waboomveld over a wide geographical range. Predominant life forms include proteoids (Protea nitida, Leucadendron salignum), narrow-leaved shrubs (Elytropappus glandulosus, Anthospermum ciliare), restioids (Restio cuspidatus, R. fruticosus) and grasses (Pentaschistis eriostoma, Themeda triandra). At the footslopes of the mountain, below the Waboomveld, karroid elements (e.g. Pteronia and Relhania spp.) are found.

Relevé 448 has no Protea nitida and few other differential species. It would seem that within Community II the species-rich Waboom stands are, in special situations, part of a wider-ranging vegetation type that lacks Protea nitida and is in general less rich in species content. This hypothesis might have important management implications and can only be tested by more sampling. Relevé 442 is the only one in Waboomveld on the northern side of the mountain. It occurs at a considerably higher altitude than any of the releves on the south side. Almost two decades ago Taylor (1963) observed that Protea nitida 'does seem to occur at higher altitudes on the northern slopes', probably to compensate for the hotter and drier conditions found there.

Community III. This community comprises relevés situated on summits and the crest fire-belt (structural units $\mathrm{C} 1 \& \mathrm{C} 2$ ), burnt just less than four years before the survey. Predominant life forms include narrowleaved shrubs (Centella virgata, Aspalathus rubens, Selago brevifolia) and restioids (Restio cuspidatus, $R$. fruticosus). The three summit relevés, Relevés 474,430 and 222 all show high scores for the grass Pentaschistis eriostoma; Ehrharta ramosa and Pentaschistis colorata also occur in the community. Relevé $\mathbf{4 3 9}$ is particularly poor in differential species. It may represent a related but undersampled community. Within Community III, this releve is the only one not situated on the main crest and that has vegetation over $1 \mathrm{~m}$ in height, suggesting that it may lie outside the four-year old firebelt.

Community $I V$. This community comprises two subcommunities, $a$ and $b$, mainly distinguished from each other by the presence in IVb of an overstorey of proteoids (Protea punctata, Leucadendron spp.) and 
the fact that IVa has no differential species. Subcommunity IVb occurs on upper southern slopes bearing the proteoid structural unit S1. In Subcommunity IVa two relevés $(432,434)$ are on upper north-facing slopes bearing the restioid structural unit Nla; one (405) is on a spur (C2) and one (472) is on a summit (C1). Therefore three structural units appear to be combined in one floristic group. On the other hand, one structural unit $(C 1)$ has three relevés $(474,430 \&$ 222 ) in floristic Community III and one (472) in IVa. The data are insufficient to determine whether these anomalies are due to fire-age or other habitat factors. They may merely show that structural units $\mathrm{Nla}, \mathrm{Cl}$ and $\mathrm{C} 2$ are not distinct entities.

Table 1 indicates that stands of lower and middle slopes, bearing the structural units N3, N4 and S3 (floristic Communities I, I and II respectively) are floristically more related to each other than to any of the other stands. The same appears to apply to stands of crests and upper slopes bearing the structural units $\mathrm{N} 1$ and S1 (floristic Communities III + IVa and IVb respectively).

The results from the structural and floristic surveys indicate that structure and species composition of the vegetation are related to major habitat factors like altitude and aspect.

\section{CONCLUDING REMARKS}

Both in the structural and the floristic surveys, we have sampled only the major matrix of fynbos communities and not the detailed patterns. Our results are therefore provisional.

The floristic survey, even a brief one like that on Rooiberg, supported and supplemented the structural survey. The latter can be done without extensive a priori knowledge of the complex fynbos flora, and has the advantage of being quicker and the data can be used by personnel with little botanical training. Emphasis is not on the plant species but rather on its functional adaptation to the environment. The structurally homogeneous units will be characterized by particular life and growth forms and can be expected to react in a reasonably uniform way to treatment such as burning, and to use such as grazing by game. The structural classification will therefore help managers to delineate management units, to determine rotation lengths and stocking rates, to maintain balanced, natural ecosystems and to monitor physiognomic changes.
In the floristic survey, emphasis is on species composition of the plant cover, and the ecological amplitudes of plant species are used to describe plant communities and their interrelationships. The floristic classification will indicate which species and communities are threatened, and will provide information on how to conserve them and how to maintain species diversity.

In conclusion, we think that a combination of a structural and floristic survey, as we have described, is a necessary and suitable basis for fynbos conservation management.

\section{ACKNOWLEDGMENTS}

For help in organizing and carrying out field work we are grateful to Forester P. Weinberg of Ladismith and a number of our colleagues and friends. We are deeply indebted to $\mathrm{Mr} \mathrm{C}$. Boucher of the Botanical Research Unit, Stellenbosch for his assistance in the computing program for Table 1.

\section{UITTREKSEL}

Die struktuur en floristiese samestelling van die plantegroei is gebruik vir die daarstelling van afsonderlike klassifikasies van plantgemeenskappe in Bergfynbos op Rooiberg, Suid-Afrika. Die str. $k$ turele eenhede en floristiese assosiasies is sterk met mekaar gekorreleer en hulle verspreiding weerspieel die vernaamste omgewingsfaktore, $n l$. aspek en hoogte bo seespieël. Ten spyte van die voorlopige aard van die opname, is die gevolgtrekking dat hulpbronopnames van hierdie aard 'n geskikte grondslag vorm vir die bestuur van natuurlike gebiede.

\section{REFERENCES}

Acocks, J. P. H., 1975. Veld types of South Africa. 2nd edn. Mem. bot. Surv. S. Afr. No. 40.128 pp.

TAYLOR, H. C., 1963. A bird's-eye view of Cape mountain vegetation. J. bot. Soc. S. Afr. 49: 17-19.

TAYIOR, H. C. 1979. Observations on the flora and phytogeography of Rooiberg, a dry fynbos mountain in the southern Cape Province, South Africa. Phytocoenologia 6: 524-531.

TAYLOR, H. C., in press. A reconnaissance of the vegetation of Rooiberg State Forest. Department of Forestry, Technical Bulletin. 
